Journal of Biology Education

\title{
Student Character Education Building on Biology Learning Through the Scientific Approach
}

\author{
Dirga Purnama $^{1}$, Hasruddin $^{1}$, Aryeni $^{2}$
}

${ }^{1,2}$ Lecturer of Biology Education, FMIPA, UNIMED

\begin{tabular}{l}
\hline Info Article \\
\hline History Articles: \\
Received : January 2019 \\
Accepted : March 2019 \\
Published: April 2019 \\
\hline Keywords: \\
character, scientific approach, \\
biology.
\end{tabular}

\begin{abstract}
The purpose of this study was to evaluate character education in students with the implementation of a scientific approach based on curriculum 2013 in the field of biological studies. The characters studied are related to honesty, discipline, cooperation, and independence of student. This descriptive study used 146 students at SMAN 1 Tebingtinggi as sample which were determined by random sampling techniques. Data was collected by questionnaire, 7 questions were about honesty, 8 questions were about discipline, 8 questions were questions about collaboration, and 7 questions were about independence. Data was analyzed by percentage technique. The results of the study showed that honest characters was at an average score of 2.73 (sufficient), the character of the discipline was at an average score of 3.11 (good), the character of cooperation was at an average score of 2.73 (enough), and independent characters was at an average score of 2.68 (enough).
\end{abstract}




\section{INTRODUCTION}

The Curriculum 2013 was implemented to replace the KTSP curriculum and has been implemented in schools since 2014. Currently, the planning and implementation process of learning including biology has been carried out by curriculum 2013. The Curriculum 2013 has been implemented by biology teachers. Fadlilah (2014) stated that curriculum 2013 became the starting point in increasing soft skills and hard skills covering cognitive aspects, attitudes, and skills.

Implementation of curriculum 2013 had many problems in the field. The results of Aeni's research, et al. (2016) found that teachers still had difficulties in applying a scientific-based approach (5M). Mustafa (2015) said that teachers' understanding of Curriculum 2013 is still inadequate, teachers have not been able to optimally apply the scientific approach and still tend to use the direct learning model because it is considered more practical and easier to achieve learning goals. Seillariski (2015), reported the obstacle faced by teachers is a lack of understanding and preparation related to the scientific approach so that the learning process with the scientific approach has not run optimally.

At present, education is faced with the demands of student success in terms of character (Budimansyah, 2010) in accordance with the mandate of Law No. 20/2003 Chapter II Article 3; high-level thinking skills (Walid et al., 2015; Heong, 2011), science process skills (Ormrod, 2009), biological literacy (Rahma, 2012), and scientific attitudes (Sanjaya, 2014). The presence of curriculum 2013 with $5 \mathrm{M}$ pattern, will be able to provide leverage in motivating students to have optimal abilities. However, after running a period of three years, it is necessary to evaluate the program which can be used as a reference in policy making for reflection and improvement of planning and implementation processes so that it can minimize the possible disadvantages.

The research problem was formulated, namely: (1) How was the description of student character in biology learning with the implementation of the $5 \mathrm{M}$ pattern through the scientific approach at SMAN 1 Tebingtinggi and (2) How could the biology teacher do so in developing student character through scientific approaches to biology at SMAN 1 Tebingtinggi. The paradigm of the scientific approach was basically an attempt to shift the view that students need to be applied in the learning process. The ability of students like a scientist needed to be done early in school. This scientific approach is basically a constructivist conceptual context, where students carry out a metacognitive process, by learning how to actually learn. Evaluation of biology learning with the application of a scientific approach has implications for improving the quality of education. As a continuation of the results of Hasruddin's research, et al (2009; 2010; 2013, 2014); Husna, et al (2014), that learning devices through the development of teaching materials can basically influence learning outcomes. The implications of this study are deemed necessary to expand the variables at the level of education in high school. Thus the research results became expanded and obtain more optimal results. Some important things that still need to be done were the development of instruments that are in line with curriculum changes and the application of a scientific approach to biology learning at the high school level.

Student character measurement, high-level thinking skills, science process skills, biological literacy, and scientific attitudes in accordance with the implementation of the scientific approach at this time need to be done as a consequence of answering the problem of students' low ability to think which still tends to the level of knowledge and understanding. although students need to implement, analyze, evaluate and create biological material content in answering future biology challenges. 
Scientific approach was an approach used in learning and carried out through scientific processes. What participants learn and get is done with their own senses and minds so that they experience directly in the process of gaining knowledge (Fadhillah, 2014). The scientific approach offered a significant breakthrough in improving the quality of learning, with the scientific approach that learning becomes more effective and can make students actively involved in classroom activities especially able to train students' abilities in speaking, listening, reading and writing skills (Zaim, 2017).

Learning with a scientific approach made students play a direct role in learning activities both individually and in groups to explore concepts and principles during learning activities and the teacher's task is to provide direction and input regarding concepts and principles that students have acquired during the learning process ( Said, 2016). The scientific approach to learning has a component of the learning process, among others: observing (observing), asking (questioning), trying (experimenting), reasoning (associating), communicating (communicating) (Sani, 2014).

Learning with a scientific approach is a learning process that is designed in such a way that students actively construct concepts, or laws or principles through the stages of observing forms, identifying or finding problems, formulating problems, submitting or formulating hypotheses, collecting data with various techniques, analyzing data, draw conclusions, and communicate concepts, laws or principles found (Deden, 2015). The scientific approach is intended to provide understanding to students in recognizing and understanding various materials using a scientific approach, that information can come from anywhere at any time and does not depend on the same direction information from the teacher. The application of a scientific approach to learning involves process skills such as observing, asking, trying, reasoning, and communicating (Selvira, 2016).

\section{RESEARCH METHOD}

This research was conducted at SMAN 1 Tebingtinggi, address Jln. Great Medan Tebingtinggi, Kodepos 41375 . The research period is six months starting from July to November 2018. The population of this study are: (1) All biology teachers who teach in class X, XI, and XII of SMAN 1 Tebingtinggi totaling 6 people; (2) All 840 students of SMAN 1 Tebingtinggi. The research sample consisted of 6 active biology teachers who were determined by total sampling technique, while for students totaling 126 people were determined proportionally random sampling, each class was represented by 42 students.

This descriptive study is used to obtain a holistic picture of the planning and implementation of biology learning processes in accordance with curriculum 2013. The evaluation referred to in this study will be obtained linkages between planning, implementation, and assessment, so that it can be used as a reference in developing policy. The data collection technique used in this study was to obtain data about the character carried out 30 questions of Likert scale. Data analysis in this study will be used descriptive statistical analysis techniques with percentage techniques.

\section{RESULTS AND DISCUSSION}

The results of the study are shown in Table 1 below. 
Table 1 Average Student Character Score

\begin{tabular}{lccccc}
\hline No & Class & Honesty & Discipline & Cooperation & Independence \\
\hline 1 & X & 2.68 & 3.11 & 2.70 & 2.58 \\
2 & XI & 2.72 & 3.09 & 2.70 & 2.67 \\
3 & XII & 2.80 & 3.14 & 2.78 & 2.79 \\
\hline
\end{tabular}

From Table 1, it can be seen that all students in class X, XI, and XII have characters in both categories of disciplinary character and have sufficient character in the character of honesty, cooperation, and independence. However, 1 out of 5 student characters namely discipline has decreased from class X to class XI and has increased again in class XII. While the other 3 characters are honesty, cooperation and independence have increased. Efforts that can be made by biology teachers in developing students' character through a scientific approach as shown in Table 2 below:

Tabel 2 Biology Teacher's Efforts in Developing Student Characters

\begin{tabular}{|c|c|c|}
\hline Number & $\begin{array}{l}\text { Biology } \\
\text { Teacher }\end{array}$ & Biology Teacher Comment \\
\hline 1 & $\mathrm{X}$ & $\begin{array}{l}\text { 1. The teacher needs to give role model to students } \\
\text { 2. Students who still have not shown a positive character should be } \\
\text { given advice. } \\
\text { 3. In biology learning, teacher should be more patient to build } \\
\text { character } \\
\text { 4. It is necessary to monitor the character of students time by time }\end{array}$ \\
\hline 2 & XI & $\begin{array}{l}\text { 1. Character evaluation is indeed difficult to do but needs to be } \\
\text { pursued as much as possible. } \\
\text { 2. Need to make and compile student character assessment rubrics. } \\
\text { 3. RPP needs to be written clearly on the character that will be } \\
\text { formed for students. } \\
\text { 4. Asking lecturers of Unimed in assessing the character of } \\
\text { students. }\end{array}$ \\
\hline 3 & XII & $\begin{array}{l}\text { 1. Teachers need to give role model for students, the philosophy of } \\
\text { Ki Hajar Dewantara still needs to be done, namely Ing Ngarso } \\
\text { Sung Tulodo, Ing Madyo Mangun Karso, and Tut Wuri } \\
\text { Handayani. } \\
\text { 2. Need to practice positive character among students. }\end{array}$ \\
\hline
\end{tabular}

In principle, education direct to character development and the end of education is character. So that, the goal of education in principle is the formation of character and personality which becomes a perfect personality. Zaini (2013) states that the process of education is not just the intellectual development of students by supplying as much knowledge as possible, more than it, Education is a process of giving understanding, knowing, and appreciating to the practices that they know. Thus, the highest goal of education is to develop students' personalities as a whole by changing the behavior and attitudes of students from negative to positive, from destructive to constructive, from bad character to noble character, including maintaining the good character they have carried.

Amri, Jauhari, \& Elisah (2011); Mulyasa (2013); and Samani \& Hariyanto (2013) stated that the success of character education programs can be known through the achievement of indicators by students as stated in the graduate standards in each school which include; (1) Practicing religious teachings adopted in accordance with the stages of human development; (2) Understanding the weaknesses and strengths of self; (3) Demonstrate an attitude of confidence; 
(4) Comply with social rules that apply in the wider environment; (5) Respect the diversity of religions, cultures, ethnicities, races, and socio-economic groups within the national scope; (6) Search for and apply information from the surrounding environment and other sources logically, critically, and creatively; (7) Demonstrate the ability to think logically, critically, creatively and innovatively; (8) Demonstrate the ability to learn independently according to their potential; (9) Demonstrate the ability to analyze and solve problems in daily life; (10) Describe natural and social symptoms; (11) Use the environment responsibly; (12) Applying togetherness values in the life of the community, nation, and state; (13) Appreciating art and culture; (14) Appreciating work assignments and having the ability to work; (15) Applying clean, healthy, fit, safe, and utilizing leisure time well; (16) Communicate and interact effectively and politely; (17) Understanding the rights and obligations of others and others in society in the community, respecting the facts of dissenting opinions; (18) Shows a penchant for reading and writing scripts; (19) Demonstrate listening, speaking, reading and writing skills; (20) Mastering the knowledge needed for further study; and (21) Having an entrepreneurship spirit.

Saptono (2002) states that the principle in embedding character education is eleven, namely: (1) Schools must be committed to core ethical values; (2) Character must be fully understood, including knowledge or understanding, feelings, and actions; (3) Schools must be proactive and act systematically in character learning and not wait and not just wait for opportunities to come; (4) Schools must build an atmosphere of mutual concern for one another and become a small world (microcosm) about caring people; (5) The opportunity to practice moral actions must be varied and available to all; (6) Study of academic matters must be the main thing; (7) Schools need to develop ways to increase students' intrinsic motivation which includes core values; (8) Schools need to work together and negotiate norms regarding character education; (9) Teachers and students must share in the school's moral leadership; (10) Parents and the community must be coworkers in character education at school; and (11) Evaluation must be made regarding the effectiveness of character education in schools, especially for teachers, employees, and students.

Samani \& Hariyanto (2013) outlines the principles of effective character education, namely: (1) Character education must promote core values (ethical core values) as a basis for the formation of good character; (2) Character must be comprehensively understood including in thoughts, feelings, and behavior; (3) Effective character education requires a genuine and proactive approach and promotes core values in all phases of life; (4) Schools must be a caring community; (5) Providing opportunities for students to take moral actions; (6) Effective character education must be equipped with a meaningful and challenging academic curriculum that respects all learners and helps them to achieve success; (7) Character education must significantly develop students' personal motivation; (8) All school staff must become learning communities and moral communities who all share responsibility for ongoing character education, and strive to develop the same core values as guidance for character education for students; (8) Implementation of character education requires moral leadership needed for school staff and students; (9) Schools must recruit parents and community members as full partners in character building efforts; and (10) Evaluation of character education must also assess the character of the school, assess the functioning of school staff as character educators, to assess how students manifest good character.

Zubaedi (2011) states that the principles used in the development of character education are: (1) Sustainability, implies that the process of developing character values is a continuous process, starting from the beginning of students to completion of an educational unit, even to 
plunge to the community; (2) Through all subjects, self-development and school culture, as well as local content; (3) Values are not merely taught, but are developed and implemented. Learning activities are carried out to develop all abilities of the cognitive, affective, and psychomotor domains; and (4) The education process is carried out actively and pleasantly by students.

Character is composed of three interconnected parts, namely: moral knowing (moral knowledge), moral feeling (moral feeling), and moral behavior (moral behavior). Good character consists of knowledge about goodness (knowing the good), desire for goodness (desiring the good), and doing good (doing the good). In this case, it is necessary to habituate in habits of mind, and habits of the heart, and habit in the action (Zubaedi, 2011). Therefore, Saptono (2002) states that to impart character to the teacher is required nine strategies as follows: (1) Acting as a caring figure, model, and mentor. In this case, the teacher treats students with love and respect, provides good examples, encourages social behavior, and improves destructive behavior; (2) Creating a moral community in the class. The teacher helps students to get to know each other, respect and care for each other, and feel valued as a group member; (3). Practice moral discipline. The teacher creates and enforces rules as an opportunity to help develop moral reasons, self-control, and appreciation to others in general; (4) Creating a democratic classroom environment. The teacher engages students in making decisions and divides responsibility in making the class a good place to develop and learn; (5) Teach values through the curriculum. The teacher used academic subjects as a means to study ethical issues; (6) Using cooperative learning. The teacher teaches students about attitudes and various skills to help one another and work together; (7) Building "Sensitivity of Conscience". The teacher helps students develop academic responsibilities and appreciate the importance of learning and working; (8) Encourage moral reflection, through reading, writing, discussing, practicing making decisions, and debating; and (9) Teaching conflict resolution, so students have the capacity and commitment to resolve conflicts fairly and fairly, in non-violent ways. According to Aushop (2014), the factors that can influence the formation of the character of students include: (1) the pattern of values instilled; (2) The idol's example; (3) Habits; (4) Rewards and penalties; and (5) Needs. Whereas Mulyasa (2013) stated that besides making exemplary and habituation as the main education method, the creation of climate and culture, as well as a conducive environment were also very important, and helped shape the character of students.

According to Thomas (1991), there are three strategies that need to be done by schools in instilling student character, namely: (1) Developing a caring attitude that is not only limited to classroom activities. This is done through role models and inspiring opportunities by serving schools and the community. In essence, students are invited to learn to be caring about how to act caring; (2) Creating a positive moral culture in schools; and (3) Involving parents of students and the community as partners in character education. In this case, the school helps parents act as the first moral teacher for the child, encouraging parents to help the school in developing efforts to develop good values.

Amri, Jauhari, \& Elisah (2011) stated that character-based education is to form a whole human with character, namely to develop physical, emotional, social, creative, spiritual, and intellectual aspects of students optimally. To form a true human learner, steps can be taken: (1) Applying a learning model that involves active participation of students (learning by doing), which is a method that can increase student motivation because all human dimensions are actively involved in being given subject matter concrete, meaningful, and relevant in the context of life (student active learning, contextual learning, inquiry-based learning, integrated learning); (2) Creating a conducive learning community, so that students can learn effectively in an 
atmosphere that provides security, appreciation, without threats, and gives enthusiasm; (3) Providing character education explicitly, systematically and continuously; and (4) Learning methods that pay attention to the uniqueness of each student, who applies all aspects of human intelligence. Mulyasa (2013) states that character education is carried out through the creation of a conducive environment, which can be done through various methods as follows: assignment, habituation, training, learning, direction, and example.

\section{CONCLUSION}

Based on the results and discussion, it can be concluded that: (1) the scientific approach implemented in curriculum 2013 on biology learning in class X, class XI, and class XII was included in the category of sufficient average on the character of honesty, independence, and cooperation, and it was included in good category on the character of discipline, and (2) Biology teachers needed to continually provide examples in building character of students by using continuous assessment used character rating rubrics.

\section{REFERENCES}

Aeni, U., Chandra, E., dan Muspiroh, N., (2016), Identifikasi Kesulitan Guru Biologi Dalam Melaksanakan Pembelajaran Kurikulum 2013 di SMA Negeri 1 Susukancirebon, Jurnal Sains dan Pendidikan Sains 5(2): 165-174.

Ahmad, H. dan D.P.A Rubba. (2003). A Study Skill Achievement among A Sample of High Ability Malaysian High School Graduates. Journal of Science and Mathematics in South East Asia. 6(1): 6369.

Anderson, L., \& Krathwohl, D. (2001). A Taxonomy for Learning, Teaching, and Assessing: A Revision of Bloom's Taxonomy of Educational Objectives. New York: Addison Wesley Longman.

Dahar, R.W. (2010). Teori Belajar. Jakarta: Erlangga.

Davis, B.G. (2013). Perangkat Pembelajaran. Jakarta: RajaGrafindo Persada.

Deden, (2015), Penerapan Pendekatan Saintifik dengan Menggunakan Model Pembelajaran Inkuiri pada Mata Pelajaran Ekonomi, Prosiding Seminar Nasional; 9 Mei 2015, 98-107.

Fadlillah, M., (2014), Implementasi Kurikulum 2013, Yogyakarta: Ar-Ruzz Media.

Good, T., Brophy, J. (2008). Looking in Classrooms. New York: Longman.

Hane, N. (2007). Use of Inquiry-Based Approach to Teaching Experimental Design Concept in a General Ecology Course. TIEE, 5(1): 1-19.

Hasruddin dan Nasution, M.Y. (2009). Inovasi Pembelajaran dengan Penerapan Pembelajaran Kontekstual untuk Meningkatkan Kemampuan Berpikir Kritis dan Kecakapan Sosial Mahasiswa pada Perkuliahan Strategi Belajar Mengajar Biologi. Laporan Penelitian Program Hibah Kompetisi Institusi (PHKI) Universitas Negeri Medan.

Hasruddin dan Nasution, M.Y. (2010). Inovasi Pembelajaran dengan Penerapan Pembelajaran Kontekstual untuk Meningkatkan Kemampuan Berpikir Kritis dan Kecakapan Sosial Mahasiswa pada Perkuliahan Biologi Umum I. Laporan Penelitian Program Hibah Kompetisi Institusi (PHKI) Universitas Negeri Medan.

Hasruddin dan Haharap, F. (2013). Pengembangan Perangkat Media Perkuliahan Mikrobiologi Terapan Berbasis Masalah. Prosiding Seminar Hasil Penelitian Universitas Negeri Medan tahun 2013. Medan: Lembaga Penelitian Unimed.

Hasruddin., Pratiwi, N., Harahap, F. (2014). The Development of Problem-Based Applied Microbiology Textbook. International Journal of Education and Research. 2(9):187-194.

Hasruddin dan Mahmud. (2013). Pengembangan Perangkat Perkuliahan Mikrobiologi Terapan Berbasis Masalah. Prosiding Seminar Nasional X. Surakarta: Prodi Pendidikan Biologi, FKIP UNS.

Heong, Y.M., Othman, W.D., Md Yunos, J., Kiong, T.T., Hassan, R., \& Mohamad, M.M. (2011). The Level of Marzano Higher Order Thinking Skills Among Technical Education Student. International Journal of Social And Humanity, 1(2): 121-125.

Hubbell, E.R. (2010). Using McREL's Knowledge Taxonomy for Ed Tech Professional Development.http://www.learningsandleading-digital.com/learningleading/20100607\#. Diakses 10 Maret 2015. 
Husna, R dan Hasruddin. (2013). Pengembangan Buku Mini Riset Mikrobiologi Terapan Berbasis Masalah. Prosiding Seminar Nasional X. Surakarta: Prodi Pendidikan Biologi, FKIP UNS.

Jacobsen, D.A., Eggen, P., Kauchak, D. (2009). Methods for Teaching. New Jersey: Allyn \& Bacon.

Kunandar. (2011). Guru Profesional. Jakarta: Rajawali Press.

Mustofa, (2015), Pemetaan Kesiapan Implementasi Pendekatanan Saintifik di SMP, Jurnal Pendidikan Geografi, 1(20): 61-67.

Noor, M. (2010). Teori dan Pendekatan Keterampilan Proses dalam Pembeljaran IPA. Jakarta: Depdikbud. Ormrod, J.E. (2009). Education Psychology, Developing Learners. Ohio: Carlisle Communication, Ltd.

Said, S., (2016), The Scientific Approach Based Cooperative Learning Tool for Vocational Students Vocation Program of Autotronic (Automotive Electronic) Engineering, IOSR Journal of Research \& Method in Education, 1(6): 67-73.

Sani, R.A., (2014). Pembelajaran Saintifik untuk Implementasi Kurikulum 2013, Jakarta: PT Bumi Aksara.

Sanjaya, W. (2008). Strategi Pembelajaran Berorientasi Standar Proses Pendidikan. Bandung: Kencana.

Sanjaya, W. (2014). Strategi Pembelajaran Berorientasi Standar Proses Pendidikan. Jakarta: Kencana.

Seillariski, I., (2015), Implementasi Pendekatan Saintifik dalam Pembelajaran Sejarah di SMA Negeri 1 Rembang., Skripsi, Semarang: FIS, Universitas Negeri Semarang.

Selvira, M., (2016), Penerapan Pendekatan Saintifik pada Siswa Kelas IV di SD Pujokusuman 1 Yogyakarta, Jurnal Pendidikan Guru Sekolah Dasar. 6(2): 511-517.

Youmi, M. (2013). Prinsip-prinsip Desin Pembelajaran. Jakarta: Kencana.

Zaim, M., (2017), Implementing Scientific Approach to Teach English at Senior High School in Indonesia, Asian Social Science, 13(2): 33-40. 